\title{
Extended Spectrum Beta-Lactamase Production and Biofilm Formation in Salmonella Serovars Resistant to Antimicrobial Agents
}

\section{-Author(s)}

Mandelli JZA' (D) https://orcid.org/0000-0002-0011-5495 Ehrhardt A" (iD https://orcid.org/0000-0002-2434-7215 Manto L' (iD) https://orcid.org/0000-0002-6269-2802 Borges KA"l (iD https://orcid.org/0000-0001-6649-5833 Furian TQIII (D) https://orcid.org/0000-0003-0376-8616 Weber Bv (D) https://orcid.org/0000-0001-6578-7105 Rodrigues LB' (D) https://orcid.org/0000-0002-4560-0988 Santos LR' (iD) https://orcid.org/0000-0002-9771-7264

Programa de pós-graduação em Bioexperimentação, Universidade de Passo Fundo, Passo Fundo, MG, Brazil.

Programa de pós-graduação em Farmacologia Terapêutica, Universidade Federal do Rio Grande do Sul, Porto Alegre, RS, Brazil.

III Centro de Diagnóstico e Pesquisa em Patologia Aviária, Faculdade de Veterinária, Universidade Federal do Rio Grande do Sul, Porto Alegre, RS, Brazil.

Iv Programa de pós-graduação em Ciências Veterinárias, Universidade Federal do Rio Grande do Sul, Porto Alegre, RS, Brazil.

\section{Mail Address}

Corresponding author e-mail address Luciana Ruschel dos Santos

Av. Brasil Leste, 285, Passo Fundo, RS, Brazil, CEP 99052-900.

Phone: +55 54 3316-8485

Email: luruschel@upf.br

\section{- Keywords}

Biofilms, drug resistance, ESBL, Salmonella.

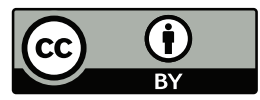

Submitted: 30/September/2018

Approved: 09/January/2019

\section{ABSTRACT}

Antimicrobial resistance is a serious public health problem and Salmonella spp. is highly resistant to antimicrobial agents. Biofilms are important in the food industry due to their formation on products, utensils, and surfaces and the difficulty in their removal. The objective of this study was to assess extended spectrum betalactamase (ESBL) production, antimicrobial resistance, and biofilm production of Salmonella isolated from poultry slaughterhouses. Antimicrobial susceptibility was assessed by the disk diffusion assay and ESBL by double diffusion disk assay using the beta-lactamase inhibitor (amoxicillin+clavulanate). The antimicrobials tested were: ampicillin, amoxicillin+clavulanate, aztreonam, ceftazidime, cefotaxime, chloramphenicol, gentamicin, enrofloxacin, sulfonamide, and tetracycline. Serovars Infantis, Panamá, and Tennessee were found to produce ESBL. All serovars were sensitive to tetracycline, and S. Brandenburg was sensitive to all drugs tested. Serovars Panamá, Anatum, Infantis, and Schwarzengrund were moderate biofilm producers at $3{ }^{\circ} \mathrm{C}$ and $9{ }^{\circ} \mathrm{C} \pm 1{ }^{\circ} \mathrm{C}$, respectively, showing possible adaptation of these serovars to these temperatures. Antimicrobials should be used with caution because of the levels of resistance observed and because of ESBL production, and hygiene and sanitary measures should be enhanced to minimize the adhesion of biofilmforming Salmonella serovars at refrigeration temperatures.

\section{INTRODUCTION}

Salmonella strains adapt to adverse environmental conditions and can survive in the environment for long periods, colonizing domestic animals and humans. The most common sources of infection among humans are products of poultry origin, dairy products, and surfaces in contact with contaminated products reused without proper disinfection, which could stimulate biofilm formation (Murray et al., 2015). Biofilm promotes bacteria survival in stressful environments, like slaughterhouses and food-processing plants (Steenackers et al., 2012). Biofilms favor greater resistance to antimicrobials and disinfectants (Steenackers et al., 2012). Antimicrobial resistance is one of the major public health problems worldwide and microorganisms isolated from foods, especially Salmonella spp., show high resistance to these agents (Markle et al., 2015). A global increase in extended spectrum betalactamase (ESBL) producing is likely to be occurring (Ziech, 2015; ECDC, 2016).

Therefore, the present study assessed antimicrobial resistance, ESBL production, and biofilm formation by Salmonella serovars isolated from poultry slaughterhouses. 


\section{MATERIALS AND METHODS}

\section{Salmonella strains}

The tested Salmonella serovars were previously isolated (Santos et al., 2015; Mion et al., 2016) from ten poultry slaughterhouses under federal inspection system between 2012 and 2014 from the northern region of the state of Rio Grande do Sul (Table 1). The samples were stored in brain heart infusion broth (Oxoid $\circledR$, United Kingdom) and frozen at $-18^{\circ} \mathrm{C}$.

Table 1 - Salmonella serovars and source of poultry slaughterhouse isolates.

\begin{tabular}{ll}
\hline Salmonella serovars & Source \\
\hline S. Agona & Transport cages after cleaning \\
S. Anatum & Cloacal swabs \\
S. Brandenburg & Chilled broiler carcasses \\
S. Bredeney & Cloacal swabs \\
S. Infantis & Transport cages after cleaning \\
S. Lexington & Transport cages after cleaning \\
S. Panamá & Cloacal swabs \\
S. Rissen & Cloacal swabs \\
S. Schwarzengrund & Cloacal swabs \\
S. Tennessee & Chilled broiler carcasses \\
\hline
\end{tabular}

\section{Antimicrobial susceptibility and ESBL production tests}

Antimicrobial susceptibility was assessed by the disk diffusion assay following the Clinical and Laboratory Standards Institute (CLSI, 2015) and the following antibiotics: ampicillin $(10 \mu \mathrm{g})$, amoxicillin+clavulanate $(20 / 10 \mu \mathrm{g})$, aztreonam $(30 \mu \mathrm{g})$, ceftazidime $(30 \mu \mathrm{g})$, cefotaxime $(30 \mu \mathrm{g})$, chloramphenicol $(30 \mu \mathrm{g})$, gentamicin $(10 \mu \mathrm{g})$, enrofloxacin $(5 \mu \mathrm{g})$, sulfonamide $(300 \mu \mathrm{g})$, and tetracycline $(30 \mu \mathrm{g})$. Interpretation was performed using the criteria described in the approved standards VET01-S2 (CLSI, 2014) and M100-S25 (CLSI, 2015). All strains classified as being moderately susceptible were considered non-susceptible.

The disk diffusion assay was used for testing ESBL production (CLSI, 2015), using amoxicillin+clavulanate placed at the center of the Mueller Hinton and three other disks were placed within a $20 \mathrm{~mm}$ radius of the first one: aztreonam, cefotaxime and ceftazidime. ESBL production was considered positive when the formation of "inhibition zones" or an increase in inhibition halo size was observed. The quality control of antimicrobials was made with E. coli ATCC 25922 and the positive control for ESBL was a K. pneumoniae ATCC 700603 strain.

\section{Biofilm-forming assay}

Biofilm-forming ability was assessed on polystyrene plates (Rodrigues et al., 2009) at the following incubation temperatures: $3 \pm 1^{\circ} \mathrm{C}$ (temperature used for refrigeration of meat cuts), $9 \pm 1^{\circ} \mathrm{C}$ (cutting room temperature for export to the European Union), $25 \pm 1^{\circ} \mathrm{C}$ (ambient temperature), $36 \pm 1^{\circ} \mathrm{C}$ (optimal pattern for the growth of mesophilic), and $42^{\circ} \mathrm{C} \pm 1^{\circ} \mathrm{C}$ (temperature for selective enrichment due to thermotolerance of Salmonella). The arithmetic mean of the absorbance values for each sample (ODa) was compared with the average absorbance of the wells containing sterile TSB (OD) and the following classification was used to determine the level of adhesion: non-adherent $(\mathrm{ODa} \leq \mathrm{OD})$, weakly adherent $(\mathrm{OD}<\mathrm{ODa} \leq 2 \mathrm{OD})$, moderately adherent (2OD $<O D A \leq 4 O D)$, strongly adherent $(4 \mathrm{OD}<\mathrm{Oda})$.

\section{RESULTS AND DISCUSSION}

Table 2 displays the susceptibility profiles of Salmonella serovars, ESBL production, and their capacity to adhere to polystyrene at different incubation temperatures.

Eight out of the 10 serovars were resistant to sulfonamides. High resistance to these drugs is probably related to their extensive use, leading to an increase in the selective pressure on resistant strains and in the dissemination of resistance genes (Machinski Junior et al., 2005; WHO, 2011; ECDC, 2016). Also, 40\% of serovars were resistant to enrofloxacin, which belongs to the class of fluoroquinolones and is exclusively used in veterinary medicine; however, despite its restricted use, it has been shown that enrofloxacin-resistant bacteria can develop resistance to ciprofloxacin. Fluoroquinolones and quinolones play a crucial role in human clinical practice, as they are used in the treatment of severe infections and are the main treatment option against salmonellosis (Souza et al., 2010; WHO, 2011).

Resistance to chloramphenicol was found to be $20 \%$, even though it cannot be used in animal production in Brazil since 2003 (Brasil, 2003). As this antimicrobial was used for many years in veterinary medicine, resistance to it might not have been reversed yet, or else, florphenicol, which is exclusively used by veterinarians, could be favoring the transmission of resistance genes that are common to these two antimicrobials (Nógrády et al., 2012; Mattiello et al., 2015). 
Table 2 - Sensitivity of Salmonella serovars, ESBL production, and adhesion to polystyrene at different incubation temperatures.

\begin{tabular}{|c|c|c|c|c|c|c|c|}
\hline \multirow{2}{*}{ Salmonella serovars } & \multirow{2}{*}{$\begin{array}{l}\text { Antimicrobial } \\
\text { resistance }\end{array}$} & \multirow{2}{*}{ ESBL production } & \multicolumn{5}{|c|}{ Adhesion to polystyrene } \\
\hline & & & $3^{\circ} \mathrm{C} \pm 1^{\circ} \mathrm{C}$ & $9^{\circ} \mathrm{C} \pm 1^{\circ} \mathrm{C}$ & $25^{\circ} \mathrm{C} \pm 1^{\circ} \mathrm{C}$ & $36^{\circ} \mathrm{C} \pm 1^{\circ} \mathrm{C}$ & $42^{\circ} \mathrm{C} \pm 1^{\circ} \mathrm{C}$ \\
\hline S. Agona & ENO, SUT & - & Non-adherent & Non-adherent & Weak & Non-adherent & Non-adherent \\
\hline S. Anatum & SUT & - & Weak & Moderate & Weak & Weak & Moderate \\
\hline S. Brandenburg & - & - & Weak & Weak & Moderate & Weak & Weak \\
\hline S. Bredeney & CLO, SUT & - & Weak & Weak & Moderate & Weak & Weak \\
\hline S. Infantis & ENO, GEN, SUT & Yes & Weak & Moderate & Moderate & Weak & Weak \\
\hline S. Lexington & SUT & - & Non-adherent & Non-adherent & Weak & Non-adherent & Weak \\
\hline S. Panamá & AMP, ENO, SUT & Yes & Moderate & Weak & Moderate & Weak & Non-adherent \\
\hline S. Rissen & SUT & - & Non-adherent & Non-adherent & Weak & Non-adherent & Weak \\
\hline S. Schwarzengrund & CLO, SUT & - & Weak & Moderate & Moderate & Weak & Weak \\
\hline S. Tennessee & ENO, GEN & Yes & Weak & Weak & Moderate & Weak & Weak \\
\hline
\end{tabular}

Legend: $\mathrm{AMP}=$ Ampicillin $10 \mu \mathrm{g}, \mathrm{CLO}=$ Chloramphenicol $30 \mu \mathrm{g}$, GEN = Gentamicin $10 \mu \mathrm{g}$, ENO = Enrofloxacin $5 \mu \mathrm{g}, \mathrm{SUT}=$ Sulfonamides $300 \mu \mathrm{g}$, TET = Tetracycline $30 \mu \mathrm{g}$. ESBL = Amoxicillin+Clavulanate 20/10 $\mu$ g, Aztreonam $30 \mu \mathrm{g}$, Ceftazidime $30 \mu \mathrm{g}$, Cefotaxime $30 \mu \mathrm{g}$.

All tested serovars were sensitive to tetracycline. Serovar Brandenburg was sensitive to all tested drugs. Serovars Anatum, Lexington, and Panamá; Agona and Tennessee; Schwarzengrund; and Infantis were considered moderately resistant to sulfonamides, enrofloxacin, chloramphenicol, and gentamicin, respectively. These are alarming findings as the assessed antimicrobials are widely used in veterinary and human medicine and also because the use of drugs with moderate resistance could result in the selection of a resistant bacterial population (Machinski Junior et al., 2005).

The number of Salmonella serotypes showing ESBL production in the current study was lower than in previous studies (Gelinski et al., 2014). Only serovars Infantis, Panamá, and Tennessee phenotypically demonstrated ESBL production, accounting for $30 \%$ of the assessed serovars. The prevalence of ESBL production strains varies worldwide. However, the incidence has increased greatly in recent years in several countries. In the study undertaken by Ziech (2015) in Brazilian samples, 45\% (44/98) of Salmonella isolates collected from birds were ESBL producers. ESBL production has emerged in serovar Infantis in Italy and Switzerland (Franco et al., 2015; Hindermann et al., 2017). Serovars Panama and Tennessee have also been reported as ESBL producers (Weill et al., 2004; Gelinski et al., 2014). ESBL-producing strains have also been described in serovars Heidelberg, Senftenberg, Newport, Enteritidis, Weltevreden, Indiana, Typhimurium, Litchfield, Oranienburg and Typhi (Jure et al., 2010; González-López et al., 2014; Bae et al., 2015; Djeffal et al., 2017).

Salmonella serovars can adhere to polystyrene, leading to biofilm formation. It is of public health concern, since strains which remain in slaughter plants and in food products could produce biofilms and favor dissemination through breakage of these structures and consequent release of pathogenic microorganisms.

Note that serovars Panamá; Anatum, Infantis and Schwarzengrund were moderate biofilm producers at $3^{\circ} \mathrm{C}$ and $9^{\circ} \mathrm{C}$, respectively, demonstrating a possible adaptation of these serovars to these temperatures. These findings are in line with those of Rodrigues et al. (2017), who observed biofilm formation at these temperatures, with strongly adherent $S$. Enteritidis strains. These findings are relevant because these serovars adhered moderately to polystyrene at unfavorable temperatures for the multiplication of Salmonella spp., which is recommended as a conventional method for food preservation under refrigeration (Gast, 2008).

The results obtained in the present study allow inferring that even if the recommended temperatures are complied with, there could be multiplication of Salmonella spp. and biofilm formation in slaughterhouses and consequent contamination of the final products, which may lead to foodborne diseases. In addition, serovars Infantis, Panamá, and Tennessee were found to produce ESBL. This is a public health problem, which highlights the need of caution in the use of antimicrobials.

\section{REFERENCES}

Bae D, Cheng CM, Khan AA. Characterization of extended-spectrum $\beta$-lactamase (ESBL) producing non-typhoidal Salmonella (NTS) from imported food products. International Journal of Food Microbiology $2015 ; 214: 12-17$

Brasil. Ministério da Agricultura, Pecuária e Abastecimento. Instrução Normativa $n^{\circ}$ 09. Proibir a fabricação, a manipulação, o fracionamento, a comercialização, a importação e o uso de princípios ativos cloranfenicol nitrofuranos e os produtos que contenham esses princípios ativos, para uso veterinário e susceptível de emprego na alimentação de todos os animais e insetos. Diário Oficial da União, 27 jun. 2003. 
CLSI - Clinical and Laboratorial Standards Institute. Performance standards for antimicrobial susceptibility testing [informational supplement, 25]. Wayne; 2015.

Djeffal S, Bakour S, Mamache B, Elgroud R, Agabou A, Chabou S, et al. Prevalence and clonal relationship of ESBLproducing Salmonella strains from humans and poultry in northeastern Algeria. BMC Veterinary Research 2017;13(132):1-9.

Donlan RM, Costerton JW. Biofilms: survival mechanisms of clinically relevant microorganisms. Clinical Microbiology Reviews 2002;15(2):167-193.

ECDPC - European Centre for Disease Prevention and Control. Fourth external quality assessment scheme for Salmonella typing [technical report]. Stockholm: ECDC; 2016

Flemming HC, Wingender J. The biofilm matrix. Nature Reviews Microbiology 2010;8(9):623-633.

Foley SL, Lynne AM. Food animal-associated Salmonella challenges:pathogenicity and antimicrobial resistance. Journal of animal Science 2008;86(Suppl 14):E173-187.

Franco A, Leekitcharoenphon P, Feltrin F, Alba P, Cordaro G, lurescia M, et al. Emergence of a clonal lineage of multidrug-resistant ESBL - producing Salmonella infantis transmitted from broilers and broiler meat to humans in Italy between 2011 and 2014. Plos One 2015;10(12):1-15.

Gast RK. Salmonella infections - paratyphoid infections. In: Saif YM, Fadly AM, Glisson JR, McDougald LR, Nolan LK, Swayne DE, editors. Diseases of poultry. Ames: Blackwell Publishing Professional; 2008. p.66-70.

Gelinski JMLN, Bombassaro A, Baratto CM, Vicente VA. Resistance to extended-spectrum $\beta$-Lactamases in Salmonella from a broiler supply chain. International Journal of Environmental Research and Public Health 2014;11(11):11718-11726.

González-López JJ, Piedra-Carrasco N, Salvador F, Rodríguez V, SánchezMontalvá A, Planes AM, et al. ESBL-Producing Salmonella enterica serovar typhi in traveler returning from Guatemala to Spain. Emerging Infectious Disease 2014;20(11):1918-1920.

Hindermann D, Gopinath G, Chase H, Negrete F, Althaus D, Zurfluh K, et al. Salmonella enterica serovar Infantis from Food and Human Infections, Switzerland, 2010-2015: poultry-related multidrug resistant clones and an emerging esbl producing clonal lineage. Frontiers in Microbiology 2017;8(1322):1-9.

Jure MA, Aulet O, Trejo A, Castillo M. Extended-spectrum $\beta$-lactamaseproducing Salmonella enterica serovar Oranienburg (CTX-M-2 group) in a pediatric hospital in Tucumán, Argentina. Revista da Sociedade Brasileira de Medicina Tropical 2010;43(2):121-124

Machinski Junior M, Benini A, Netto DP, Nunes MP, Vedovello Filho D, Benatto $A$, et al. Medicamentos veterinários utilizados na avicultura de postura no Estado do Paraná. Curitiba: PAMvet-PR; 2005. 24p.

Markle WH, Fisher MA, Smego RA Jr. Compreendendo a saúde global. 2 ed. Porto Alegre: Artmed; 2015
Mattiello SP, Drescher G, Barth VC Jr, Ferreira CA, Oliveira SD. Characterization of antimicrobial resistance in Salmonella enterica strains isolated from Brazilian poultry production. Antonie Van Leeuwenhoek 2015;108(5):1227-1238.

Mion L, Parizotto L, dos Santos LA, Webber B, Cisco IC, Pilotto F,et al. Salmonella spp. isolated by miniaturized most probable number and conventional microbiology in poultry slaughterhouses. Acta Scientiae Veterinariae 2016;44(1393):1-5.

Murray P, Rosenthal KS, Pfaller MA. Microbiologia médica. $7^{\text {th }}$ ed. Rio de Janeiro: Elsevier Health Sciences; 2015.

Neves GB. Diferenças na expressão gênica de isolados de campo e de frigorífico da Salmonella resistente aos antimicrobianos e desinfetantes [dissertation]. Florianópolis (SC): Universidade do Estado de Santa Catarina; 2014

Nógrády N, Király M, Davies R, Nagy B. Multidrug resistant clones of Salmonella Infantis of broiler origin in Europe. International Journal of Food Microbiology 2012;157(1):108-112

Rodrigues LB, Santos LR, Pilotto F, Silva CF, Gehlen SS, Diedrich LN, et al. Biofilm formation at different incubation temperatures by Salmonella Enteritidis. Brazilian Journal of Microbiology; 2017. In press.

Rodrigues LB, Santos LR, Rizzo NN, Tagliari VZ, Oliveira AP, Trenhago G, et al. Avaliação da hidrofobicidade e da formação de biofilme em poliestireno por Salmonella Heidelberg isoladas de abatedouro avícola. Acta Scientiae Veterinariae 2009;37(3):225-230.

Santos LA, Mion L, Marotzki M, Parizotto L, Rodrigues LB, do Nascimento VP, et al. Número mais provável miniaturizado e microbiologia convencional para isolamento de Salmonella spp. em abatedouros de frangos de corte. Pesquisa Veterinária Brasileira 2015;35(3):223-229

Souza RB, Magnani M, Oliveira TCRM. Mecanismos de resistência às quinolonas em Salmonella spp. Semina: Ciências Agrárias 2010;31(2):413

Steenackers H, Hermans K, Vanderleyden J, De Keersmaecker SCJ. Salmonella biofilms: an overview on occurrence, structure, regulation and eradication. Food Research International 2012;45:502-531.

Weill FX, Demartin M, Fabre L, Grimont PAD. Extended-Spectrum- $\beta$ Lactamase (TEM-52)-Producing Strains of Salmonella enterica of Various Serotypes Isolated in France. Journal of Clinical Microbiology 2004;42(7):3359-3362.

WHO - World Health Organization. critically important antimicrobials for human medicine. Geneva: WHO; 2011.

Ziech RE. Caracterização de Salmonella sp. isolada de indústrias de aves baseada na formação de biofilmes, tolerância a sanitizantes e resistência a antimicrobianos [dissertation]. Curitiba (PR): Universidade Federal do Paraná; 2015. 